\title{
EFEKTIVITAS PENERAPAN MODEL PROBLEM BASED LEARNING DENGAN KOMBINASI PENDEKATAN SAINTIFIK DAN PROBLEM POSING DALAM PEMBELAJARAN MATEMATIKA
}

\author{
Al Jibra \\ Program Studi Pendidikan Matematika, Program Pascasarjana \\ Universitas Negeri Makassar \\ email: aljibra89@gmail.com
}

\begin{abstract}
ABSTRAK
Penelitian ini bertujuan untuk mengetahui keefektifan penerapan model problem based learning dengan kombinasi pendekatan saintifik dan problem posing dalam pembelajaran matematika. Jenis penelitian ini adalah penelitian pre-eksperimen.populasinya adalah semua siswa kelas VIII SMP Negeri 5 Pallangga Kabupaten Gowa yang jumlahnya enam kelas, sedangkan sampelnya adalah kelas VIII c yang diambil secara acak. Hasil analisis deskriptif menunjukan bahwa data hasil belajar matematika peserta didik pada pre-test bahwa nilai rata-rata berada pada kategori sangat rendah, sedangkan pada post-test nilai rata-rata berada pada kategori tinggi. Tingkat ketuntasan secara klasikal pada pretest dalam kategori tidak tuntas, sedangkan pada post-test dalam kategori tuntas, ratarata gain ternormalisasi berada pada kategori sedang. Aktifitas peserta didik pada pertemuan terakhir berada pada waktu ideal, serta respon peserta didik berada pada kategori positif dengan skor rata-rata respons peserta didik mencapai 3,67. Hasil analisis inferensial menggunakan uji one sample t-test dengan bantuan SPSS 20 untuk menguji hipotesis menunjukkah bahwa data hasil belajar peserta didik pada post-test signifikan dengan nilai $\alpha=0,05$, sedangkan pada gain ternormalisasi signifikan dengan nilai $\alpha=0,05$, serta data respon peserta didik signifikan dengan nilai $\alpha=0,05$. Berdasarkan hasil analisis deskriktif dan inferensial dapat disimpulkan bahwa penerapan model problem based learning dengan kombinasi pendekatan saintifik dan problem posing efektif di kelas VIII SMP Negeri 5 Pallangga Kabupaten Gowa.
\end{abstract}

Kata kunci : Problem Based Learning, Pendekatan Saintifik. Pendekatan Problem Posing

\begin{abstract}
The research aims to discover the effectiveness of the implementation of problem based learning model combined with scientific approach and problem posing in mathematics learning. The research is pre-experiment. The population is all students of pallangga gowa pubric junior high school grade VIII, and the sample is all students of close VIII.c randomly selected. The result of descriptive analysis reveals that the data of the students' learning result in pre-test shows the mean is in very low category. Whereas the post-test shows that the mean score is in high category'. the level of classical mastery in pre-test is in incomplete category while in post-test is in complete category, the mean of normalized gain in medium category, and the students' activity in the last meeting is in ideal time, and the students' response is in positive category with the mean score of the students' response reaches 3.67. The result of the inferential analysis of one sample t- test with the help of SPSS 20 shows that the data of the students' learning result in post-test is significant with a by 0.05, while the normalized gain is significant with a 0.05, and the data of the students' response is significant with a 0,05. The conclusion based on the result of descriptive and inferential analysis is the implementation of problem based learning model combined with scientific approach and problem posing in mathematics learning is effective in class VIII at SMP Negeri 5 Pallangga District Gowa.
\end{abstract}

Keywords : Problem Based Learning, Scientific Approach, Problem Posing 


\section{PENDAHULUAN}

Salah satu ilmu pengetahuan dasar yang menunjang ilmu pengetahuan lain adalah Matematika, Matematika bukan hanya mengajarkan keterampilan berhitung, bukan hanya keterampilan mengerjakan soal, bukan hanya aspek praktis yang dikejar. Tapi, matematika juga mengajarkan aspek-aspek lain berupa kecermatan, ketelitian, berpikir logis, bertanggung jawab, disiplin, hingga keimanan. Walaupun Matematika salah satu ilmu pengetahuan yang mendukung ilmu lain dan bahkan dipelajari baik pendidikan informal, formal maupun nonformal. Akan tetapi sebagian besar peserta didik menganggap matematika itu salah satu pelajaran yang menakutkan karena berhubungan dengan perhitungan rumus, definisi dan teorema.

Hal tersebut menuntut guru untuk menciptakan proses belajar-mengajar matematika yang menyenangkan dan komunikatif dengan inovasi model mengajar yang menarik dan melibatkan semua peserta didik untuk berpartisipasi aktif dalam proses pembelajaran berlangsung sehingga peserta didik belajar matematika dengan tidak terpaksa. Guru dituntut dapat memilih model pembelajaran yang dapat memacu semangat setiap peserta didik untuk secara aktif ikut terlibat dalam pengalaman belajarnya. Salah satu alternative model pembelajaran yang memungkinkan dikembangkanya keterampilan berpikir peserta didik (penalaran, komunikasi, dan koneksi) dalam memecahkan masalah adalah model problem based learning.

Menurut Tan (Rusman, 2013) model problem based learning merupakan inovasi dalam pembelajaran karena dalam model problem based learning kemampuan berpikir peserta didik betul-betul dioptimalisasikan melalui proses kerja kelompok atau tim yang sistematis, sehingga peserta didik dapat memperdayakan, mengasah, menguji, dan mengembangkan kemampuan berpikir secara berkesinambungan. Sejalan dengan pendapat Tan, Boud dan Feletti (Rusman, 2013) mengemukakan bahwa model problem based learning adalah inovasi yang paling signifikan dalam pendidikan. Margetson (Rusman, 2013) mengemukakan bahwa model problem based learning membantu untuk meningkatkan perkembangan keterampilan belajar sepanjang hayat dalam pola pikir yang terbuka, reflektif, kritis, dan belajar aktif.

Perubahan cara pandang terhadap peserta didik sebagai objek menjadi subjek dalam proses pembelajaran menjadi titik tolak banyak ditemukanya berbagai pendekatan pembelajaran yang inovatif. Ivor K. Davis (Rusman, 2013) mengemukakan bahwa "salah satu kecenderungan yang sering dilupakan adalah melupahkan bahwa hakikat pembelajaran adalah belajarnya peserta didik dan bukan mengajarnya guru".

Sejalan dengan pergantian kurikulum 2013, istilah pendekatan ilmiah atau scientific aproach pada pelaksanaan pembelajaran menjadi bahan pembahasan yang menarik perhatian para pendidik akhir-akhir ini. Hal ini memerlukan peningkatan keterampilan guru melaksanakan pembelajaran dengan menggunakan pendekatan ilmiah. Skenario untuk memacu keterampilan guru menerapkan strategi ini di Indonesia telah melalui sejarah yang panjang, namun hingga saat ini harapan baik ini belum terwujudkan juga.

Pembelajaran dengan pendekatan saintifik adalah proses pembelajaran yang dirancang sedemikian rupa agar peserta didik secara aktif mengonstruk konsep, hukum atau prinsip melalui tahapan-tahapan mengamati (untuk mengidentifikasi atau menemukan masalah), merumuskan masalah, mengajukan atau merumuskan hipotesis, mengumpulkan data dengan berbagai teknik, menganalisis data, menarik kesimpulan dan mengomunikasikan konsep, hukum atau prinsip yang "ditemukan". Pendekatan saintifik dimaksudkan untuk memberikan pemahaman kepada peserta didik dalam mengenal, memahami berbagai materi menggunakan pendekatan ilmiah, bahwa informasi bisa berasal dari mana saja, kapan saja, tidak bergantung pada informasi searah dari guru. Oleh karena itu kondisi pembelajaran yang diharapkan tercipta diarahkan untuk mendorong peserta didik dalam mencari tahu dari berbagai sumber melalui observasi, dan bukan hanya diberi tahu.

Sejalan dengan pendekatan saintifik terdapat juga sebuah pendekatan pembelajaran yang telah lama digunakan didunia pendidikan iyaitu pendekatan problem posing. Pendekatan problem posing atau pengajuan masalah merupakan pendekatan pembelajaran yang mengharuskan peserta didik menyusun pertanyaan sendiri atau memecah suatu soal menjadi pertanyaan-pertanyaan yang lebih 
sederhana yang mengacu pada penyelesaian soal tersebut.

Pendekatan problem posing juga dapat diartikan sebagai suatu pendekatan dalam pembelajaran matematika dimana peserta didik diminta untuk merumuskan, membentuk dan mengajukan pertanyaan atau soal dari situasi yang disediakan. Dengan demikian, sikap kritis, rasa ingin tahu dan kreatifitas peserta didik akan tereksplorasi. Sikap kritis dan rasa ingin tahu merupakan sifat alamiah yang dimiliki oleh manusia. Sifat ini menjadi motivator bagi seseorang untuk terus menambah pengetahuan. Melihat tujuan dari kedua pendekatan saintifik dan problem posing yang menuntut peserta didik untuk menemukan sendiri masalah dan penyelesaiannya. Sehingga sangat mungkin kedua pendekatan ini dapat dikombinasikan pada suatu proses pembelajaran.

Berdasarkan latar belakang masalah yang telah dikemukakan di atas, maka rumusan masalah dalam penelitian ini adalah: (1) Seberapa besar tingkat hasil belajar peserta didik setelah penerapan model problem based learning dengan kombinasi pendekatan saintifik dan problem posing di kelas VIII SMP Negeri 5 Pallangga Kabupaten Gowa? (2) Seberapa besar tingkat aktivitas peserta didik terhadap penerapan model problem based learning dengan kombinasi pendekatan saintifik dan problem posing di kelas VIII SMP Negeri 5 Pallangga Kabupaten Gowa? (3) Seberapa besar tingkat respon peserta didik terhadap penerapan model problem based learning dengan kombinasi pendekatan saintifik dan problem posing di kelas VIII SMP Negeri 5 Pallangga Kabupaten Gowa? (4) Apakah penerapan model problem based learning dengan kombinasi pendekatan saintifik dan problem posing efektif di kelas VIII SMP Negeri 5 Pallangga Kabupaten Gowa?

Pembelajaran merupakan sub-set khusus pendidikan. Menurut Tim Penyusun Kamus (1993) pembelajaran adalah kata benda yang diartikan sebagai proses, cara, menjadikan orang atau makhluk hidup belajar. Kata ini berasal dari kata kerja belajar yang berarti berusaha untuk memperoleh kepandaian atau ilmu, merubah tingkah laku atau tanggapan yang disebabkan oleh pengalaman. Dari pengertian pembelajaran tersebut menunjukkan bahwa pembelajaran berpusat pada kegiatan peserta didik belajar dan bukan berpusat pada kegiatan guru mengajar.
Oleh karena itu pada hakikatnya pembelajaran matematika adalah proses yang sengaja dirancang dengan tujuan untuk menciptakan suasana lingkungan memungkinkan seseorang (si pelajar) melaksanakan kegiatan belajar matematika, dan proses tersebut berpusat pada guru mengajar matematika. Pembelajaran matematika harus memberikan peluang kepada peserta didik untuk berusaha dan mencari pengalaman tentang matematika.

Dalam batasan pengertian pembelajaran yang dilakukan di sekolah, pembelajaran matematika dimaksudkan sebagai proses yang sengaja dirancang dengan tujuan untuk menciptakan suasana lingkungan (kelas/sekolah) yang memungkinkan kegiatan peserta didik belajar matematika sekolah.

Problem based learning (pembelajaran berbasis masalah) mulai pertama kali diterapkan di McMaster University School of Medicine Kanada pada tahun 1969 (Rianto, 2010). Rianto (2010) mengungkapkan bahwa dalam problem based lerning peserta didik dipandang sebagai pribadi "yang utuh" yang memiliki sejumlah pengetahuan sebagai bekal awal dalam pembelajaran.

Problem based learning adalah suatu model pembelajaran yang menuntut peserta didik untuk berpikir kritis, memecahkan masalah, belajar secara mandiri, dan menuntut keterampilan berpartisipasi dalam tim. Proses pemecahan masalah dilakukan secara kolaborasi dan disesuaikan dengan kehidupan (Barrows \& Kelson, dalam Trianto, 2010). Duch (Trianto, 2010) menyatakan bahwa problem based learning adalah suatu model pembelajaran yang menghadapkan peserta didik pada tantangan "belajar untuk belajar". Peserta didik aktif bekerja sama di dalam kelompok untuk mencari solusi permasalahan dunia nyata. Permasalahan itu sebagai acuan bagi peserta didik untuk merumuskan, menganalisis, dan memecahkan.

Problem based learning (pembelajaran berbasis masalah) merupakan strategi pembelajaran dengan menghadapkan peserta didik pada permasalahan-permasalahan praktis sebagai pijakan dalam belajar atau dengan kata lain peserta didik belajar melalui permasalahanpermasalahan. Menurut Fogarty, Boud dan Felleti strategi belajar berbasis masalah merupakan suatu pendekatan pembelajaran dengan membuat konfrontasi kepada peserta 
didik dengan masalah-masalah praktis (Wena, 2009).

Pendekatan saintifik dimaksudkan untuk memberikan pemahaman kepada peserta didik dalam mengenal, memahami berbagai materi menggunakan pendekatan ilmiah, bahwa informasi bisa berasal dari mana saja, kapan saja, tidak bergantung pada informasi searah dari guru. Oleh karena itu kondisi pembelajaran yang diharapkan tercipta diarahkan untuk mendorong peserta didik dalam mencari tahu dari berbagai sumber melalui observasi, dan bukan hanya diberi tahu.

Penerapan pendekatan saintifik dalam pembelajaran melibatkan keterampilan proses seperti mengamati, mengklasifikasi, mengukur, meramalkan, menjelaskan, dan menyimpulkan. Dalam melaksanakan proses-proses tersebut, bantuan guru diperlukan. Akan tetapi bantuan guru tersebut harus semakin berkurang dengan semakin bertambah dewasanya peserta didik atau semakin tingginya kelas peserta didik.

Langkah- langkah pendekatan saintifik dalam pembelajaran disajikan sebagai berikut, (1) Mengamati, (2) Menanya, (3) Mengumpulkan Informasi, (4) Mengasosiasikan/Mengolah Informasi/Menalar,

Menarik Kesimpulan, dan

Mengkomunikasikan.

Pendekatan problem posing menurut Brown dan Walter (Upu, 2003) dinyatakan bahwa pengajuan masalah matematika terdiri dari dua aspek penting, yaitu accepting dan challenging. Accepting berkaitan dengan kemampuan peserta didik memahami situasi yang diberikan oleh guru atau situasi soal yang sulit ditentukan. Sementara challenging, berkaitan dengan sejauh mana peserta didik merasa tertantang dari situasi yang diberikan sehingga melahirkan kemampuan untuk mengajukan masalah matematika. Hal ini berarti bahwa pengajuan masalah matematika dapat membantu peserta didik untuk mengembangkan proses nalar mereka.

Menurut Silver (Muhfida, 2010) problem posing mempunyai beberapa arti. Pertama, problem posing adalah perumusan soal sederhana atau perumusan ulang soal yang ada dengan beberapa perubahan agar lebih sederhana dan dapat dikuasai. Kedua, problem posing adalah perumusan soal yang berkaitan dengan syarat-syarat pada soal yang telah dipecahkan atau alternatif soal yang masih relevan. problem posing dimaksudkan perumusan masalah (soal) oleh peserta didik dari situasi yang tersedia atau soal yang diberikan oleh guru, yang dilakukan sebelum, ketika dan setelah pemecahan masalah misalnya guru mengajukan masalah/soal kepada peserta didik, selanjutnya peserta didik diminta mengajukan pertanyaan-pertanyaan (masalahmasalah) yang mengarah kepada pemecahan masalah. Ketiga, problem posing yaitu merumuskan atau membuat soal dari situasi yang diberikan.

Berdasarkan uraian di atas tampak bahwa pembelajaran matematika dengan pendekatan problem posing akan sangat bermanfaat, karena dengan pembelajaran problem posing dapat meningkatkan kemampuan berpikir kreatif dan kritis dari peserta didik. Namun dapat ditarik kesimpulan bahwa pendekatan problem posing adalah suatu pendekatan pembelajaran dimana peserta didik diminta untuk merumuskan, membentuk dan mengajukan pertanyaan atau soal dari situasi yang disediakan.

Dengan menggabungkan tahap problem posing menurut pendapat Brown dan Walter (Accepting dan Challenging), dengan pendapat Hamzah Upu (situasi masalah, pengajuan masalah, pemecahan masalah) serta tahap dalam pengembangan berpikir kreatif (Persiapan,Inkubasi, Iluminasi, dan Verifikasi) dapat disusun langkah-langkah pendekatan problem posing (Era waluyo dan Mintohari,2013), yaitu (a) Persiapan, penyampaian tujuan pembelajaran dan menggali pengetahuan awal peserta didik tentang materi; (b) Pemahaman, penjelasan singkat guru tentang materi yang akan dipelajari peserta didik; (c) Situasi Masalah, pemberian situasi masalah atau informasi terbuka pada peserta didik, situasi masalah dapat berupa study kasus atau informasi terbuka berupa teks dan gambar; (d) Pengajuan masalah, peserta didik mengajukan pertanyaan dari situasi masalah atau informasi terbuka yang diberikan guru; (e) Pemecahan masalah, peserta didik memberikan jawaban atau penyelesaian soal dari pertanyaan yang telah diajukan oleh peserta didik; (f) Verifikasi, mengecek pemahaman peserta didik terhadap materi yang dipelajari.

Kombinasi Pendekatan saintifik dan Problem Posing merupakan Pembelajaran dengan pendekatan saintifik, yaitu proses pembelajaran yang dirancang sedemikian rupa 
agar peserta didik secara aktif mengonstruk konsep, hukum atau prinsip melalui tahapantahapan mengamati, menanya, mengumpulkan informasi, mengasosiasikan/ mengelola imformasi/ menalar, menarik kesimpulan, dan mengkomunikasikan.

Pendekatan saintifik menuntut peserta didik untuk aktif dalam proses pembelajaran, hal ini sejalan dengan pendekatan problem posing. Pendekatan problem posing dapat membantu peserta didik dalam mengembangkan keyakinan dan kesukaan terhadap matematika, sebab ide-ide matematika peserta didik dicobakan untuk memahami masalah yang sedang dikerjakan dan dapat meningkatkan performannya dalam pemecahan masalah. Pengajuan soal juga sebagai sarana komunikasi matematika peserta didik. Oleh karena itu, problem posing dapat menjadi salah satu alternatif untuk mengembangkan berpikir matematis atau pola pikir matematis.

Dalam problem posing, peserta didik diberi kegiatan untuk membuat/membentuk soal kemudian menyelesaikan/memecahkan soal tersebut sesuai dengan konsep atau materi yang telah dipelajari dengan tahapan pendahuluan, pengembangan penerapan, dan penutup.

Tujuan dan karakteristik kedua pendekatan menuntun peserta didik untuk menemukan sendiri, sehingga kedua pendekatan ini sangat dapat dikombinasikan, Sehingga dapat disusun sebuah skenario pembelajaran dengan menggunakan model pembelajaran problem based learning dan peranan pendekatan saintifik dan problem posing.dengan dmikian tujuan penelitian ini adalah untuk: (1) besarnya tingkat hasil belajar peserta didik setelah penerapan model problem based learning dengan kombinasi pendekatan saintifik dan problem posing di kelas VIII SMP Negeri 5 Pallangga Kabupaten Gowa. (2) Besarnya tingkat aktifitas peserta didik terhadap penerapan model problem based leararnig dengan kombinasi pendekatan saintifik dan problem posing di kelas VIII SMP Negeri 5 Pallangga Kabupaten Gowa. (3) Besarnya tingkat respon peserta didik terhadap penerapan model problem based learning dengan kombinasi pendekatan saintifik dan problem posing di kelas VIII SMP Negeri 5 Pallangga Kabupaten Gowa. (4) Efektifitas penerapan model problem based learning dengan kombinasi pendekatan saintifik dan problem posing di kelas VIII SMP Negeri 5 Pallangga Kabupaten Gowa.
Hipotesis yang diajukan dalam penelitian ini adalah "Penerapan problem based learning dengan kombinasi pendekatan saintifik dan problem posing efektiv dalam pembelajaran matematika di kelas VIII SMP Negeri 5 Pallangga Kabupaten Gowa".

\section{METODE PENELITIAN}

Jenis penelitian yang digunakan adalah eksperimen semu pre-eksperiment atau Desain eksperimen pretest post test . Menurut Sugiyono (2011) desain ini belum merupakan eksperimen sungguh-sungguh, karena masih ada variabel luar yang ikut berpengaruh terhadap terbentuknya variabel dependen.

Populasi dalam penelitian ini adalah semua peserta didik kelas VIII SMP Negeri 5 Pallangga Kabupaten Gowa dan tersebar dalam enam kelas paralel. Sampel pada penelitian ini adalah kelas VIII C yang dipilih dari enam kelas paralel dengan menggunakan teknik Simple Random Sampling yaitu teknik pengambilan sampel yang dilakukan secara acak, karena peserta didik di keenam kelas paralel tersebut diasumsikan homogen dalam hal kemampuan matematika.

Variabel yang diselidiki dalam penelitian ini adalah hasil belajar peserta didik, aktivitas peserta didik, dan respons peserta didik.

Untuk mengumpulkan data dalam penelitian ini digunakan dengan cara sebagai berikut: (1) Data hasil belajar dikumpulkan dengan menggunakan tes hasil belajar matematika. (2) Data aktivitas peserta didik dikumpulkan dengan menggunakan lembar observasi aktivitas peserta didik dalam pembelajaran. (3) Data respons peserta didik terhadap pembelajaran dikumpulkan dengan menggunakan angket respons peserta didik.

Teknik Analisis Data. Untuk analisis statistik deskriptif digunakan pendapat Menurut Sugiyono (2011) yang menyatakan bahwa statistik deskriptif adalah statistik yang digunakan untuk menganalisis data dengan cara mendeskripsikan atau menggambarkan data yang telah dikumpul sebagai adanya tanpa bermaksud membuat kesimpulan yang berlaku untuk umum atau generalisasi. Data yang dianalisis secara deskriptif yaitu: data hasil pengamatan aktivitas 
peserta didik, hasil respons peserta didik, dan hasil tes belajar peserta didik. Ukuran pengkatagoriannya adalah sebagai berikut:

Tabel 1. Interprestasi Kategori Nilai Hasil Belajar

\begin{tabular}{cc}
\hline Interval Nilai & Kategori \\
\hline $90,00-$ & Sangat Tinggi \\
100,00 & Tinggi \\
$80,00-89,99$ & \\
\hline
\end{tabular}

\begin{tabular}{cc}
\hline Interval Nilai & Kategori \\
\hline $65,00-79,99$ & Sedang \\
$55,00-64,99$ & Rendah \\
$0,00-54,99$ & Sangat \\
& Rendah
\end{tabular}

Untuk analisis penggunaan waktu ideal penyelesaian tugas yang dilakukan siswa digunakan pedoman pengkategoriannya sebagai berikut:

Tabel 2. Penentuan Kesesuaian Aktivitas Peserta Didik Berdasarkan Pada Pencapaian Waktu Ideal

\begin{tabular}{ccc}
\hline $\begin{array}{c}\text { Aspek Pengamatan Aktivitas Peserta } \\
\text { didik }\end{array}$ & \multicolumn{2}{c}{ Persentase Kesesuaian (P) } \\
\cline { 2 - 3 } $\begin{array}{c}\text { Memperhatikan dan merespon petunjuk } \\
\text { dan arahan dari guru }\end{array}$ & $30 \%$ & $25 \%-35 \%$ \\
$\begin{array}{c}\text { Mengerjakan masalah yang disajikan pada } \\
\text { LKPD 1 }\end{array}$ & $10 \%$ & $5 \%-15 \%$ \\
$\begin{array}{c}\text { Meminta bimbingan/bantuan pada guru } \\
\text { Mengajukan masalah berdasarkan situasi } \\
\text { yang diberikan pada LKPD 2 }\end{array}$ & $25 \%$ & $20 \%-30 \%$ \\
$\begin{array}{c}\text { Menyelesaikan masalah yang telah } \\
\text { diajukan }\end{array}$ & $10 \%$ & $5 \%-15 \%$ \\
$\begin{array}{c}\text { Mempresentasikan hasil kerja di papan } \\
\text { tulis }\end{array}$ & $15 \%$ & $10 \%-20 \%$ \\
$\begin{array}{c}\text { Memberikan kesimpulan materi yang telah } \\
\text { dipelajari }\end{array}$ & $5 \%$ & $0 \%-10 \%$ \\
$\begin{array}{c}\text { Melakukan aktivitas lain di luar kegiatan } \\
\text { pembelajaran }\end{array}$ & $0 \%$ & $0 \%-10 \%$ \\
\hline
\end{tabular}

Untuk Analisis statistik inferensial yang digunakan dalam peneliti ini terdiri dari : (1) Uji Normalitas, Uji normalitas digunakan untuk mengetahui apakah populasi yang diteliti terdistribusi normal atau tidak. Pengujian normalitas data motivasi dan kemampuan pemecahan masalah menggunakan sistem Statistical Package for Social Science (SPSS) versi 20.0. Data akan berdistribusi normal apabila sig $>\alpha$ dengan taraf nyata $\alpha=0,05$. (2) Uji hipotesis, Setelah data dinyatakan berdistribusi normal, maka memenuhi syarat dilakukan uji hipotesis dengan menggunakan statistik uji $t$ (one sample $t$ test) pada taraf signifikasi $\alpha=0,05$.

\section{HASIL DAN PEMBAHASAN}

\section{Hasil}

Berdasarkan hasil belajar matematika peserta didik, pembelajaran model problem based learning dengan kombinasi pendekatan saintifik dan problem posing dikatakan efektif. Hasil belajar matematika peserta didik pada pre- 
test berada pada kategori rendah dengan nilai mean 39,87 dan deviasi standar 8,99, sedangkan pada post-test berada pada kategori tinggi nilai mean 81,53 dan standar deviasi 5,59 serta tingkat ketuntasan secara klasikal pada pre-test sebesar $100 \%$ dalam kategori tidak tuntas sedangkan pada post-test sebesar $89,58 \%$ dalam kategori tuntas. Hasil uji hipotesis hasil belajar peserta didik menunjukkan bahwa terdapat peningkatan rata-rata nilai gain ternormalisasi secara signifikan.

Berdasarkan aktivitas peserta didik, pembelajaran model problem based learning dengan kombinasi pendekatan saintifik dan problem posing dikatakan efektif. Aktivitas peserta didik pada pertemuan terakhir pembelajaran berada pada interval toleransi pencapaian waktu ideal.

Berdasarkan respons peserta didik, pembelajaran model problem based learning dengan kombinasi pendekatan saintifik dan problem posing dikatakan efektif. Respons peserta didik secara deskriptif berada pada kategori positif dengan skor rata-rata 3,67 dan secara signifikansi rata-rata skor respons peserta didik yang diajar dengan pembelajaran model problem based learning dengan kombinasi pendekatan saintifik dan problem posing lebih dari 3,49 .

Keefektifan Pembelajaran Model Problem Based Learning dengan Kombinasi Pendekatan Saintifik dan Problem Posing ditunjukkan oleh hasil belajar matematika peserta didik pada materi peluang ditinjau dari tingkat kemampuan peserta didik berada pada kategori tinggi dengan ketuntasan klasikal mencapai mencapai $89,58 \%$ serta pengetahuan peserta didik menunjukan peningkatan yang signifikan setelah belajar dengan menerapkan pembelajaran model problem based learning dengan kombinasi pendekatan saintifik dan problem posing. Aktivitas peserta didik minimal berada pada kategori sangat baik, dan respons peserta didik terhadap perangkat dan pembelajarannya berada pada kategori positif. Hal ini dibuktikan dengan rata-rata hasil belajar matematika peserta didik lebih besar dari 74,9 (KKM) yaitu 81,53 dengan standard deviasi sebesar 5,59 dari skor ideal 100, serta nilai ratarata gain ternormalisasi peserta didik lebih besar dari 0,29 yaitu 0,69 dengan standard deviasi sebesar 0,074 dari skor ideal 1 berada pada klasifikasi sedang, ketuntasan hasil belajar peserta didik secara klasikal sebesar $89,58 \%$ lebih besar dari $84,9 \%$, aktivitas peserta didik berada pada interval toleransi pencapaian waktu ideal dan rata-rata skor respon peserta didik terhadap pembelajaran berada pada kategori positif iyaitu sebesar 3,67 lebih besar dari 3,49 (positif).

\section{Pembahasan}

Hasil penelitian ini menunjukan bahwa hasil belajar matematika peserta didik yang diajar dengan pembelajaran model problem based learning dengan kombinasi pendekatan saintifik dan problem posing ditinjau dari tingkat kemampuan peserta didik berada pada kategori tinggi dengan tingkat ketuntasan klasikal mencapai mencapai $89,58 \%$ serta pengetahuan peserta didik menunjukan peningkatan yang signifikan setelah belajar dengan menerapkan pembelajaran model problem based learning dengan kombinasi pendekatan saintifik dan problem posing.

Secara keseluruhan, pembelajaran model problem based learning dengan kombinasi pendekatan saintifik dan problem posing dapat meningkatkan kemampuan peserta didik dalam memahami materi Peluang, hal ini ditunjukan oleh klasifikasi gain ternormalisasi bahwa hasil belajar peserta didik berada pada kategori tinggi.

Hasil pengamatan terhadap aktivitas peserta didik menunjukkan bahwa pada pertemuan terakhir memenuhi interval toleransi pencapaian waktu ideal. Kedelapan kategori aktivitas tersebut memenuhi interval toleransi pencapaian waktu ideal (PWI). Pencapaian ini menunjukkan bahwa aktivitas peserta didik yang diharapkan terpenuhi.

Aktivitas peserta didik yang aktif tidak terlepas dari usaha guru yang selalu merefleksi pelaksanaan pembelajaran yang telah dilakukan sebelumnya termasuk bagaimana agar aktivitas peserta didik yang diharapkan tercapai. Bentuk aktivitas peserta didik dalam kelas misalnya memperhatikan dan merespon petunjuk dan arahan dari guru, mengerjakan masalah yang disajikan pada LKPD 1, Meminta bimbingan/bantuan pada guru, Mengajukan masalah berdasarkan situasi yang diberikan pada LKPD 2, menyelesaikan masalah yang telah 
diajukan, mempersentasikan hasil kerja di papan tulis, serta memberikan kesimpulan materi yang telah dipelajari.

Hasil penelitian ini menunjukan bahwa respons peserta didik yang diajar dengan pembelajaran model problem based learning dengan kombinasi pendekatan saintifik dan problem posing berada pada kategori positif dengan skor rata-rata respons peserta didik mencapai 3,67. Dengan belajar dengan pembelajaran model problem based learning dengan kombinasi pendekatan saintifik dan problem posing, peserta didik dapat lebih bersemangat untuk belajar matematika. Penerapan pembelajaran model problem based learning dengan kombinasi pendekatan saintifik dan problem posing dalam pembelajaran matematika di kelas, memberikan kesempatan kepada peserta didik untuk mengajukan dan menjawab masalah berdasarkan situasi yang diberikan.

Secara keseluruhan, pembelajaran model problem based learning dengan kombinasi pendekatan saintifik dan problem posing dapat meningkatkan kemampuan peserta didik dalam memahami materi peluang, hal ini ditunjukan oleh klasifikasi gain ternormalisasi bahwa mayoritas peserta didik berada pada kategori sedang. Pembelajaran ini juga menunjukkan aktivitas peserta didik yang baik dalam belajar dan memberikan kesempatan yang luas bagi peserta didik untuk berinteraksi dengan guru secara langsung, dalam hal menyampaikan keluhan atau permasalahan yang dihadapi oleh peserta didik tentang materi peluang. problem based learning, memberi kemudahan bagi peserta didik untuk memahami konsep materi yang dipelajari karena peserta didik dituntuk untuk menyelesaikan masalah yang diberikan sehingga dapat memahami materi. saintifik dan problem posing memberikan kesempatan kepada peserta didik untuk menajukan dan menyelesaiakn masalah dari situasi yang diberikan berdasarkan konsep materi yang telah dipahami.

\section{SIMPULAN DAN SARAN}

Berdasarkan rumusan masalah, tujuan penelitian dan hasil penelitian serta pembahasan yang diperoleh sebagaimana yang telah diuraikan, adapun kesimpulan yang dapat ditarik dari penelitian ini adalah: a. Hasil belajar matematika peserta didik kelas VIII SMP Negeri 5 Pallangga Kabupaten Gowa setelah diterapkan pembelajaran model problem based learning dengan kombinasi pendekatan saintifik dan problem posing berada pada klasifikasi sedang, dengan nilai rata-rata lebih dari 74,9 (KKM) yaitu 81,53 dengan standard deviasi sebesar 5,59 dari skor ideal 100. Selain itu, nilai rata-rata gain ternormalisasi peserta didik sebesar 0,69 dengan standard deviasi sebesar 0,074 dari skor ideal 1. Sedangkan ketuntasan hasil belajar peserta didik secara klasikal sebesar $89,58 \%$.

b. Aktivitas peserta didik pada pembelajaran model problem based learning dengan kombinasi pendekatan saintifik dan problem posing memenuhi interval toleransi pencapaian waktu ideal.

c. Respon peserta didik terhadap pembelajaran model problem based learning dengan kombinasi pendekatan saintifik dan problem posing berada pada kategori positif, dengan nilai rata-rata sebesar 3,67 lebih dari 3,49 (positif).

d. Penerapan model problem based learning dengan kombinasi pendekatan saintifik dan problem posing efektif di kelas VIII SMP Negeri 5 Pallangga Kabupaten Gowa.

Berdasarkan hasil penelitian yang telah dicapai dalam penelitian ini, maka dikemukakan beberapa saran sebagai berikut:

a. Model pembelajaran problem based learning dengan kombinasi pendekatan saintifik dan problem posing dalam pembelajaran matematika hendaknya dapat menjadi bahan pertimbangan dalam memilih model pembelajaran di sekolah dan dijadikan sebagai alternatif pilihan guru dalam pembelajaran terutama untuk mata pelajaran matematika. Hal ini disebabkan karena strategi pembelajaran tersebut dapat meningkatkan pemahaman konsep dan hasil belajar peserta didik, melibatkan aktivitas peserta didik secara optimal, serta memfasilitasi peserta didik menemukan dan membangun pengetahuannya.

b. Bagi guru dan peneliti selanjutnya yang menggunakan model pembelajaran problem based learning dengan kombinasi pendekatan saintifik dan problem posing diharapkan dapat lebih mengembangkannya agar benar-benar dapat membantu peserta 
didik dalam memahami materi pelajaran yang diajarkan.

c. Bagi peneliti lain, diharapkan dapat mengkaji lebih dalam mengenai model pembelajaran problem based learning dengan kombinasi pendekatan saintifik dan problem posing agar mampu menyelesaikan masalah pendidikan lebih mendalam.

\section{DAFTAR RUJUKAN}

Era Waluyo dan Mintohari. 2013. Penerapan Pendekatan Problem Posing (Pengajuan Masalah) Untuk Meningkatkan Kemampuan Berpikir Kreatif Pada Siswa Sekolah Dasar. Jurnal Online Universitas Negeri Surabaya http://www.scribd.com/doc/14727 1103/PENERAPANPENDEKATAN-PROBLEMPOSING-PENGAJUANMASALAH-UNTUKMENINGKATKANKEMAMPUAN-BERPIKIRKREATIF-PADA-SISWASEKOLAH-DASAR\#scribd

Muhfida. 2010. Pelaksanaan Pendekatan Problem Posing (Online). (http://blog.muhfida.com/pelaksan aan-pendekatan-problem-posing, diakses 10 Januari 2011).

Rianto, Yatim. 2010. Paradigma Baru Pembelajaran. Jakarta: Kencana Prenada Media Group.

Rusman. 2013. Model-Model Pembelajaran Mengembangkan Profesionalisme Guru. Jakarta: RajaGrafindo Persada.

Sugiyono, 2011 Metode Penenlitian Kuantitatif Kualitatif Dan $R \& D$. Bandung: Alfabeta

Tim Penyusun Kamus. 1993. Kamus Besar Bahasa Indonesia Jilid II. Jakarta : Balai Pustaka.

Trianto. 2010. Mendesain Model Pembelajaran Inovatif-Progresif: Konsep Landasan, dan Implementasinya Pada Kurikulum Tingkat Satuan Pendidikan (KTSP). Jakarta: Kencana.

Upu, Hamzah. 2003. Problem Posing dan Problem Solving dalam
Pembelajaran

Matematika.

Bandung: Pustaka Ramadhan 